O. V. Posylkina, V. G. Kotlyarova, O. V. Chechotka

National University of Pharmacy

\title{
ANALYSIS OF PECULIARITIES OF GROWTH FOR THE MEDICAL COSMETICS MARKET IN UKRAINE
}

The article investigates growth trends and industry peculiarities of the Ukrainian medical cosmetics market. A number of market factors and competitive factors were investigated. The analysis has shown that the Ukrainian medical cosmetics market exhibits features steady growth trends and is a market with a high degree of product differentiation and competition. The factors analyzed determine the peculiarities of the medical cosmetics market.

Key words: medical cosmetic products; medical cosmetics market structure; medical cosmetics brands

\section{STATEMENT OF THE PROBLEM}

A goods market is an area for exchange of goods between manufacturers and consumers which has been established on the basis of differentiation of labor. A system of relationships between manufacturers and consumers forms the structure of a goods market. The type and kind of relationships depend on the features of the goods market. The factors that form the peculiarities of a particular goods market include: nature and significance of products being on sale on the market; government regulation of the activities of the market participants; purchase ability of consumers and others.

Medical and cosmetic products are on sale on the market for medical and cosmetic products, which is a segment of the Ukrainian pharmaceutical market.

\section{ANALYSIS OF RECENT RESEARCH AND PUBLICATIONS}

Over recent years, scientists have conducted research on some aspects of the functioning of the medical and cosmetic products market. For instance, as for the classification of skin care products, their differentiation and purpose, according to O. Gudz and O. Bashura, "care products for skin, appendages of skin, teeth, oral cavity mucous membrane, genitals, etc., being brought to the Ukrainian market can be divided into 2 groups: cosmetic products and medical cosmetic products" [1]. Research conducted by A. Olkhovska, M. Kobets, L. Felonenko [6], S. Zhakhalova [1] deals with the analysis of the participants of the Ukrainian medical cosmetics market. The papers review the structure of the range of medical cosmetic products being on sale on

(c) Posylkina O. V., Kotlyarova V. G., Chechotka O. V., 2016 the Ukrainian market, segment consumers of medical cosmetics, identify consumer preferences for medical cosmetics brands reviewed, rank the most important criteria for consumers when choosing medical cosmetic products.

\section{IDENTIFICATION OF ASPECTS OF THE PROBLEM UNSOLVED PREVIOUSLY}

The analysis of literature references on medical cosmetics market research has shown that no attention had been paid to the issues determining the peculiarities of this market.

\section{OBJECTIVE STATEMENT OF THE ARTICLE}

The purpose of the article is to investigate the condition and growth trends of the Ukrainian medical cosmetics market and specific features of competitive struggle on this market.

\section{PRESENTATION OF THE MAIN \\ MATERIAL FOR THE RESEARCH}

The medical cosmetics market emerged in Western Europe in the 30's of the 20th century and has gained rapid growth over a period of 50 years. During this period, more than 20 research laboratories appeared, and on their basis medical cosmetics manufacturing companies were established.

Currently, on the Ukrainian market one can purchase medical cosmetics by manufacturers such as BABE, Divination Simone, DeLuxe, PfC, Cosmetics Sesderma (Spain); CAUDALIE, Algotherm, Laboratoires SVR, Avène, NUXE, RoC, A-Derma, Phyto, Lierac, Filorga, Uriage, Bioderma, Ducray, Biorga (France); Declare, Excipial, Swissclinical (Switzerland); Doliva, EUCERIN, Jean, d'Arcel, Placen Formula (Germany); Fresh Look, LEOREX, Premier by 
INFORMATION ABOUT THE DISTRIBUTORS OF MEDICAL AND COSMETIC PRODUCTS IN UKRAINE

\begin{tabular}{|l|l|l|}
\hline \multicolumn{1}{|c|}{ Distributor } & \multicolumn{1}{|c|}{ Type of Distributor } & \multicolumn{1}{c|}{ Brands } \\
\hline Cosmed, PJSC & National & Vichy (France) \\
\hline Marko Pharm, LLC & Exclusive & Bioderma, Uriage, Avène, A-Derma (France) \\
\hline Cosmomedfarm, LLC & Official & CHI, CHI, Organics, Biosilk, SunGlitz (USA) \\
\hline Fresh Beauty Boutique & Exclusive & PREMIER by Dead Sea, LEOREX (Israel) \\
\hline SDM-Pharma, LLC & Exclusive & $\begin{array}{l}\text { Uriage, SVR, Klytia, Bailleul-Biorga (France), } \\
\text { Seaderm (Belgium), Dr Belter (Germany) }\end{array}$ \\
\hline
\end{tabular}

Dead Sea (Israel); Optima (Italy), Seaderm Laboratoires (Belgium, France); SOLUTIONS (Netherlands), Research and Production Association FitoBioTehnologii, LLC, Research and Production Association BIOCON, Research and Production Company ECOTECH (Ukraine) and others.

Medical and cosmetic products get on the Ukrainian market by establishing exclusive distribution. Table 1 shows information about the distributors of medical and cosmetic products that operate on the domestic pharmaceutical market.

Medical cosmetics products are promoted through exclusive distribution. Most often, distributors supply the products to pharmacy networks.

It should be noted that over the past five years the Ukrainian medical cosmetics market has changed not merely in quantitative terms, but also in terms of structure. Thus, according to the research [6], in $2011,90 \%$ of all medical cosmetics on sale on the Ukrainian market were of foreign production: 40\% from France; $10 \%$ from Germany; $11 \%$ from Italy; $7 \%$ from Slovenia and Poland; the remaining $25 \%$ from Spain, Scotland, Russia and England. Accordingly, $10 \%$ of the sales of medical cosmetics were products of domestic production. The most popular brands of foreign production: Vichy, Avene, RoC, Uriage, Lireac, Klorane. From domestic production customers preferred products by brands such as Hirudo Derm, Bishoff, Cosmedfarm and Talita.

As of the beginning of 2016, the market structure has slightly changed: the relative share of medical cosmetics from France has increased to $44 \%$ and from Russia to $4.2 \%$; and that from Germany has reduced to $7 \%$. Medical cosmetics from Israel have become firmly established on the Ukrainian market with a relative share of more than $7 \%$. The relative share of Ukrainian manufacturers has reduced to $8.5 \%$.

Currently, Ukrainian preferences for choosing imported products have somewhat changed due to an increasing number of consumers of Israeli medical cosmetics including some of the most wellknown brands such as Dead Sea, Ahava, Premier,
Sea of SPA, etc. Among domestic brands, as according to a 2011 study, medical cosmetics by brands such as Hirudo Derm (Medical Research and Production Association BIOCON) and Bishoff (Research and Production Company ECOTECH) are most in demand. As of the beginning of 2016, Cosmomedfarm, LLC is the official distributor for CHI, CHI Organics, Biosilk, SunGlitz (USA) in Ukraine. Over the period since 2011, no new domestic manufacturers of medical cosmetics have appeared in Ukraine. Research and Production Association FitoBioTehnologii, LLC (manufacture of cosmetic products for treatment and prevention of couperose and rosacea) is the only exception. Several manufacturers whose products have appeared on the Ukrainian market in recent years are marketing their products as medicinal cosmetics, but at the same time they set out in the specification that these take effect only in the upper layer of the epidermis. These are companies such as Euro Plus, LLC and Eliksir Ukraina, LLC.

There is horizontal product differentiation within the segment of medical cosmetics. Table 2 provides information on the number of lines of facial skin care products by brands that are most in demand in Ukraine.

Studies of the features of facial skin care lines by brands that are most in demand in Ukraine showed the following. The total number of medical cosmetic lines for facial skin care by only five mentioned brands amounts to 41 lines of 250 products. In the context of highly differentiated product markets the issues related to effective product promotion are likely to become a problem for manufacturers.

With dozens of products intended for the same purpose (as for instance, sensitive skin care products, dehydrated skin care products, etc.) being available on the market, the manufacturer is required to highlight, as far as possible, its very own product.

Within this framework, it is the issue of effective use of modern marketing strategies and promotion technologies for medical cosmetics that is becoming particularly urgent. 
INFORMATION ABOUT THE MEDICAL COSMETIC LINES FOR FACIAL SKIN CARE

\begin{tabular}{|c|c|c|}
\hline Brand & $\begin{array}{c}\text { Number of } \\
\text { product lines }\end{array}$ & Purpose \\
\hline Vichy (France) & 13 & $\begin{array}{l}\text { For problem and oily skin }(5) * ; \\
\text { Cleansing line for any skin type }(7) ; \\
\text { Moisturization and nutrition }(3) ; \\
\text { Color defect correction line }(12) ; \\
\text { Dry skin line (8); } \\
\text { Products designed to combat the first mimic wrinkles (4); } \\
\text { Age-related wrinkle correction line (6); } \\
\text { Skin lifting and firming products }(4) ; \\
\text { Product line designed to increase tightness of fading skin (11); } \\
\text { Fading skin care line }(9)\end{array}$ \\
\hline $\begin{array}{l}\text { Avene } \\
\text { (France) }\end{array}$ & 14 & $\begin{array}{l}\text { Basic care (7); } \\
\text { Sensitive skin care (5); } \\
\text { Eye contour care (2); } \\
\text { Supersensitive skin (4); } \\
\text { Dehydrated skin (4); } \\
\text { Skin redness: erythros, couperose (7); } \\
\text { Damaged skin (3); } \\
\text { Dry and very dry skin (5); } \\
\text { Atopic and dry skin }(6) ; \\
\text { Oily skin, problem-prone juvenile skin, acne skin (2); } \\
\text { Anti-aging products }(4) ; \\
\text { Special products for men (4); } \\
\text { Sunscreen products }(2)\end{array}$ \\
\hline $\begin{array}{l}\text { Uriage } \\
\text { (France) }\end{array}$ & 7 & $\begin{array}{l}\text { Anti-age care Isofill, Peptilys (10); } \\
\text { Hypersensitive skin Peaux sensibles (11); } \\
\text { Depigmentation care Depiderm (2); } \\
\text { Daily care AquaPRECIS, Suppleance (12); } \\
\text { Dermatological care (16); } \\
\text { Hyseac (12); } \\
\text { Thermal water (3) }\end{array}$ \\
\hline $\begin{array}{l}\text { Hirudo Derm } \\
\text { (Ukraine) }\end{array}$ & 5 & $\begin{array}{l}\text { Care program for dry, very dry and dehydrated facial skin (5); } \\
\text { Care program for skin with age-related changes, prevention of wrinkles (4); } \\
\text { Care program for oily and combination skin, treatment and prevention of acne (7); } \\
\text { Care program for sensitive skin (5); } \\
\text { Against pigmented spots (3) }\end{array}$ \\
\hline
\end{tabular}

* - the number of products included in a single product line is given in parentheses

The research conducted has allowed to identify the main features peculiar to the Ukrainian medical cosmetics market:

- With the integration processes being developed, the domestic medical cosmetics market becomes more and more influenced by the world market trends;

- Over the past five years, the Ukrainian medical cosmetics market has been narrowing; however, it remains a very promising niche for domestic manufacturers;

- The medical cosmetics market exhibits strong growth in innovation processes; the range of medical cosmetic products that are available on the domestic market continues to widen;

- In the near term, the market for medical cosmetics is heavily influenced (much more than the market for medicines) by external factors, including: level of income (budget constraints); price increase; foreign exchange rates; credit and deposit rates;

- The domestic market for medical cosmetic products overlaps to a considerable extent with the market for cosmetic products; as of today, cosmetic products by more than 300 manufacturers are on sale in Ukrainian pharmacies; 
EXAMPLES OF DISEASES FOR TREATMENT OF WHICH BOTH MEDICINES AND MEDICAL COSMETIC PRODUCTS ARE USED

\begin{tabular}{|c|c|c|}
\hline Disease & Medicines & Medical cosmetic products by brands \\
\hline Eczema & \multirow{2}{*}{$\begin{array}{l}\text { Laticort cream, Cortomycetin ointment, } \\
\text { Hyoxysonum ointment; Beloderm ointment } \\
(\text { cream) }\end{array}$} & A-Derma, Avène, Bioderma (France) \\
\hline Psoriasis & & $\begin{array}{l}\text { Thermal waters Avène, Uriage (France), } \\
\text { Premier by Dead Sea (Israel) }\end{array}$ \\
\hline Keratosis & Fluorouracil cream, Fluoroplex and Carac & Uriage (France) \\
\hline
\end{tabular}

- By value, the Ukrainian medical cosmetics market is dominated by products from foreign manufacturers (70\% of the market); by volume, it is dominated by products from domestic manufacturers (60\% of the market);

- The cost of domestic medical cosmetics is 3.5 to 4 times lower than that of imported products;

- Over recent years, the share of medical cosmetics being on sale in domestic pharmacies has amounted on an average to $5 \%$ by value and $3 \%$ by volume;

- The maximum sales are registered for the group of medical cosmetics "Facial skin care products" and "Hair care products";

- There is a clear tendency to reduce the average age of consumers of medical cosmetics;

- Women are the main consumers of medical cosmetics in Ukraine; however, there is a steady trend of increasing demand for cosmetics for men, for mobile medical cosmetics (that is suitable for use on on business trips, travels, holidays);

- There is a growing interest of consumers for medical cosmetics which allows professional treatment procedures to be provided at home;

- The average margin on medical cosmetics is higher than that on medicines and amounts, on an average, to $100 \%$, while that on medicines is 25 to $30 \%$;

- The average marginality for medical cosmetics is higher by 6 to $9 \%$ compared to conventional cosmetic products;

- Among the product groups that are available in domestic pharmacies medical cosmetics traditionally rank $2^{\text {nd }}$ or $3^{\text {rd }}$ in terms of profitability;

- In pharmacies, innovative positioning knowhows for medical cosmetic products are not sufficiently used; the level of consulting and diagnostic services for these products is inadequate;

- Not enough attention is paid to the problem of training and re-training of pharmaceutists in terms of effective promotion and sales of medical cosmetics;

- The costs for medical cosmetics promotion are continuously rising due to increased competition;
- There exists uneven regional distribution of medical cosmetics; the pharmacies located in the regions with a high consumer purchasing power such as Kyiv, Kyiv region, Odessa, Dnipro, Kharkiv show significantly larger sales volumes of this product range;

- The legal and regulatory framework relating to medical cosmetics in Ukraine requires serious improvement.

As noted above, the medical cosmetics market features a high level of competition, which according to expert opinion, will continue to grow in the future. To choose a reasonable strategy to promote medical cosmetic products it is important to study the specific features of competitive struggle on the given market and its main parameters.

M. Porter's model of competitive forces describes the three parameters that must be considered in the analysis of competition on the industry market: the level of threat from substitute products; the level of intra-industry and industry competition; the threat of entry of new competitors [7].

By definition, a substitute product is a product which meets the same needs as the specific product [7]. The purpose of using medical cosmetic products is to prevent and treat dermatological problems of the skin. Medicines are used with the same end in view. The examples of diseases for treatment of which both medicines and medical cosmetic products are used are given in Table 3.

Hence, medical cosmetic products have substitute products on the pharmaceutical market. Moreover, based on the results of the conducted research, consumer confidence of medicines is much higher than of medical cosmetic products. The main reasons are as follows:

- Medical and cosmetic products are less traditional when used for treatment $-21 \%$ of those surveyed;

- Attitude towards medical and cosmetic products is as towards cosmetics only (no treatment effect) $-17 \%$ of those surveyed;

- High price of medical cosmetic products with uncertainty about the effect of their use $-16 \%$ of those surveyed.

Therefore, to reduce the competition intensity from substitute products, manufacturers and dis- 
tributors of medical cosmetics should conduct an active outreach campaign on the peculiarities and benefits of using in certain cases just medical and cosmetic products.

According to CIDESCO classification developed by the International Committee of Aesthetics and Cosmetology, medical and cosmetic products and cosmetic products are included in the same group of skin care products. According to this classification, cosmetic products are divided into the following segments: mass market, middle market, luxury, pro and cosmeceuticals (medical and cosmetic products) [3]. However, cosmetic products are not substitute products for medical cosmetics. The purpose of using cosmetic products is to meet consumer needs for hygiene skin care; that of using medical cosmetic products to prevent and treat dermatological problems of the skin.

Despite the different purpose of use of medical cosmetics and cosmetic products, consumers perceive them as substitute products. This is particularly so with the organic cosmetics segment.

The map was created based on the results of the expert survey of consumers in Kharkiv, Kyiv, Lviv regions; the number of respondents was 278.

The analysis of the perception of the above products showed the following:

- As the main differential characteristics of the products used for skin care, the study group of consumers chose "purpose of the product price";

- To address skin problems consumers prefer to take medicines, while medical cosmetics are perceived as cosmetic products;

- Organic and natural cosmetic products are perceived by consumers as medical and cosmetic products;

- "Luxury" and "Pro" cosmetics are identical to medical cosmetics according to the consumers. The research on consumer characteristics of skin care products has shown that such perception of these products is false.

1. Medicines and medical and cosmetic products differ in a number of features such as scope and purpose of exposure, API concentration, type of action, level of exposure and other characteristics; therefore, their stereotyped identification is incorrect.

2. The identification of medical and cosmetic products and organic cosmetics is also incorrect. Consumers perceive the organicity of a product as therapeutic effect. In the consumers' mind the association "natural = healthy = effective" [4] is consistently formed. However, this perception is not truth. The organicity of products means organic principles used for its production; so, organic cos- metics must include at least $95 \%$ of ingredients of natural origin; plants that are part of cosmetics are grown by organic farming; certified manufacturers of organic cosmetics deliberately abandoned the use of chemical components that are typical ingredients of the classical cosmetic products [5]. Hence, the organicity of products does not guarantee any therapeutic effect. For instance, according to the description of organic products by brands ArgaLine Lab. KosmoPharm (Morocco), BIOselect (Greece), Canaan Minerals \& Herbs, Herbs of Kedem (Israel), Eco Cosmetics (Eco Cosmetics), Lavera, Logona (Germany), Green Energy Organics (Italy), Retsepty babushky Ahaf'y (Russia), Madara (Latvia), Vigor Cosmetique Naturelle (Ukraine), Bioscreen Paris (France) and others, they protect, regenerate, tone, soothe, soften, increase elasticity, restores the hydrolipidic layer of skin, protecting it against dryness and irritation, heal wounds, cracks. That is to say, they do not penetrate deeper than the epidermis, unlike medical and cosmetic products that penetrate all layers of the skin.

3 . The research conducted has shown that 42$45 \%$ of the female population of Ukraine use medical cosmetic products. The main parameters by which they choose products are: efficacy, safety, brand recognition, ease of use. Only $6 \%$ of those surveyed mentioned the price as a parameter of the selection of a product. For consumers who do not use any medical cosmetics, the price parameter was the most important with $35 \%$ of those surveyed. Therefore, $67 \%$ of those surveyed use organic cosmetic products, mistakenly believing that they get therapeutic effect at a lower cost; $33 \%$ use medicines, taking into account an average lower cost of a product package.

4. "Luxury" cosmetics are perceived by consumers as being close in characteristics to medical cosmetics due to their high price. However, according to the characteristics, the latter performs only hygienic, preventive and aesthetic functions. The high price is due to the safer composition of these products and high level of technology used. "Pro" cosmetics are perceived by consumers as being medical, due to the fact that these are used by cosmetologists in beauty salons, and they provide quick aesthetic effect.

Therefore, in an effort to change the consumer's perception about medical cosmetics, a reasonable strategy of their repositioning is required.

\section{CONCLUSIONS}

1. The analysis of product sales volumes on the Ukrainian medical cosmetics market has shown a steady trend for its growth. Over the period under examination the market has changed not only in quantitative terms, but also in terms 
of structure (based on manufacturers and consumers). The share of domestic products remains virtually unchanged on the medical cosmetics market.

2. The medical cosmetics market has a high level of competition. Products by more than 50 foreign and domestic manufacturers are on sale on the market.

3. The Ukrainian medical cosmetics market is a highly differentiated product market. It renders difficult the task for manufacturers to isolate their own products in a number of similar products. Under these conditions, especially relevant is the problem of effective use of modern marketing strategies and promotion technologies for medical cosmetics.

4. Medical cosmetic products are used by $42-45 \%$ of women in Ukraine. The study of perception of these products by consumers that do not use has revealed that this perception is false. Therefore, in order to improve the promotion of medical cosmetic products a reasonable strategy of repositioning is required.

5. As noted above, the domestic medical cosmetics market is highly competitive and constantly updated with new foreign and domestic participants, and features quite a high potential for growth. All this makes it possible to draw a conclusion on need of using modern scientific approaches and advanced marketing technologies for the successful promotion of these products and improving of the competitive posi- tions of domestic manufacturers of medical and cosmetic products.

\section{REFERENCES}

1. Гудзь О. Косметичні засоби та засоби лікувальної косметики. Спільність форми і розбіжності у складі та показаннях до застосування / О. Гудзь, О. Башура // Клінічна рармація. - 2000. - Т. 4, № 1. - С. 41-43.

2. ЖКахалова С. Маленький да удаленький: обзор рынка лечебной косметики / С. Жахалова // Провизор. - 2008. - № 7. - С. 4-9.

3. Классификация косметических средств. - Режим доступу: http://mk-up.ru/klassifikaciyakosmetiki

4. Косметика в аптеке: Тренды продвижения // Аптека online.ua. - 2013. - № 913 (42). - Режим доступу: http://www.apteka.ua/ article

5. Международные стандарты органик. - Режим доступу: http://organic-eco.com.ua/ index.php?show_aux_page $=1$

6. Ольховська А. Маркетингові дослідження вітчизняного ринку лікувальної косметики / А. Ольховська, М. Кобець, Л. Фелоненко // Управління, економіка та забезпечення якості в фармації. - 2011. - № 3 (17). С. 63-67.

7. Портер Майкл Е. Конкурентная стратегия: методика анализа отраслей и конкурентов / Майкл Е. Портер: пер. с англ. - М. : Альпина Бизнес Букс, 2005. - 454 с. 


\section{УДК 616.12.687.55.339.138}

О. Посилкіна, В. Котлярова, О. Чечотка

АНАЛІЗ ОСОБЛИВОСТЕЙ РОЗВИТКУ РИНКУ ЛІКУВАЛЬНОї КОСМЕТИКИ В УКРАЇНІ

Ринок лікувальної косметики України, недивлячись на деяке сповільнення за період кризи 2008-2009 рр., має стійку тенденцію до зростання. На теперішній час на фармацевтичному ринку представлені засоби понад 100 закордонних та вітчизняних виробників у співвідношенні 93:7. Найпопулярнішими торговими марками імпортного виробництва є: Vichy, Avene, RoC, Uriage, Lireac, Klorane. Серед продукції вітчизняного виробництва споживачі віддавали перевагу засобам торгової марки Hirudo Derm. На ринок України лікувально-косметичні засоби потрапляють шляхом налагодження ексклюзивної дистрибуції. Проведені дослідження дозволили визначити головні риси, притаманні ринку лікувальної косметики в Україні. Ринок лікувальної косметики характеризується високим рівнем конкуренції, який буде в подальшому зростати. Висока інтенсивність конкуренції спостерігається як з боку виробників лікувально-косметичних засобів, які давно представлені на ринку, так і з боку товарів-субститутів. Як показав проведений аналіз, сприйняття споживачами лікувально-косметичних засобів сьогодні є помилковим. 3 метою зміни споживацького сприйняття щодо засобів лікувальної косметики необхідна обгрунтована стратегія їх репозиціонування.

Ключові слова: лікувально-косметичні засоби; структура ринку лікувальної косметики; торгові марки лікувальної косметики

\section{УДК 616.12.687.55.339.138}

О. Посылкина, В. Котлярова, Е. Чечотка

\section{АНАЛИЗ ОСОБЕННОСТЕЙ РАЗВИТИЯ РЫНКА ЛЕЧЕБНОЙ КОСМЕТИКИ В УКРАИНЕ}

Рынок лечебной косметики Украины, несмотря на некоторое замедление за период кризиса 2008-2009 гг., имеет стойкую тенденцию увеличения. В настоящее время на фармацевтическом рынке представлены средства свыше 50 зарубежных и отечественных производителей в соотношении 93:7. Наиболее популярными торговыми марками импортного производства являются: Vichy, Avene, RoC, Uriage, Lireac, Klorane. Среди продукции отечественного производства потребители отдают преимущество средствам торговой марки Hirudo Derm. Проведенные исследования позволили определить главные черты, присущие рынку лечебной косметики в Украине. Рынок лечебной косметики характеризуется высоким уровнем конкуренции, который будет в дальнейшем расти. Высокая интенсивность конкуренции наблюдается как со стороны производителей лечебно-косметических средств, которые давно представлены на рынке, так и со стороны товаров-субститутов. Как показал проведенный анализ, восприятие потребителями лечебно-косметических средств сегодня является ошибочным. С целью изменения потребительского восприятия относительно средств лечебной косметики необходима обоснованная стратегия их репозиционирования.

Ключевые слова: лечебно-косметические средства; структура рынка лечебной косметики; торговые марки лечебной косметики

Адреса для листування:

61140, м. Харків, вул. О. Невського, 18.

Тел. (057) 771-81-47.

E-mail: kaf.yep@nuph.edu.ua.

Національний фармацевтичний університет
Надійшла до редакції 10.10.2016 p. 